\title{
Electrochemical Separation of Metal Silver from Industrial Wastewater
}

\author{
M. A. Olutoye*, J. A. Alhamdu \\ Department of Chemical Engineering, Federal University of Technology, Minna, Nigeria \\ Email: ${ }^{*}$ remnickolutoye@yahoo.com
}

Received 6 February 2014; revised 6 March 2014; accepted 26 March 2014

Copyright (C) 2014 by authors and Scientific Research Publishing Inc.

This work is licensed under the Creative Commons Attribution International License (CC BY). http://creativecommons.org/licenses/by/4.0/

c) (i) Open Access

\begin{abstract}
Investigation into the separation of metal silver from industrial wastewater using electrochemical cell was carried out. Wastewater from photo laboratories was collected and treated batch wise using electrolytic equipment. A constant voltage of $2.0 \mathrm{~V}$ and variable current in the range of 0.3 $0.6 \mathrm{~A}$ at normal temperature were passed through the electrolyte for a period from $0.25-1.0 \mathrm{~h}$. The results showed that increase in current yield an increase in the amount of metallic silver recovered with highest values of $2.3 \mathrm{~g}$ and $2.8 \mathrm{~g}$ at $0.6 \mathrm{~A}$ for the tested samples 1 and 2 , respectively. The electrochemical separation method proved to be more reliable and economical when compared to other methods and also, reduction in environmental pollution of industrial wastewater containing high concentration of silver metal is achieved.
\end{abstract}

\section{Keywords}

\section{Silver Metal, Electrochemical, Separation, Wastewater, Environment}

\section{Introduction}

Silver is valued as ornamental and coinage metal since ancient times. It is a precious metal with a number of industrial applications especially in photo imaging being the most malleable and ductile of all metals. Separation of silver metal from photo-processing wastewater is of particular interest because of its unique qualities, reduction in environmental discharge of metal contaminated wastewater, and the rapid decline in availability from natural sources whereby preservation is of great concern. Free silver in photographic processing solutions has been recognized as an efficient bactericidal and as such could affect the biological and ecological balance of the system [1]. Thus, its removal from photographic wastewater leads to a much cleaner environment by minimizing the potential water pollution. Heavy metal pollutants, such as silver constitute a very serious form of pollution

*Corresponding author.

How to cite this paper: Olutoye, M.A. and Alhamdu, J.A. (2014) Electrochemical Separation of Metal Silver from Industrial Wastewater. Advances in Chemical Engineering and Science, 4, 396-400. http://dx.doi.org/10.4236/aces.2014.44043 
because they usually form stable compounds that are not readily removed by oxidation, precipitation or any other natural process. Silver is said to be toxic and poisonous to the enzyme system, as well as having an affinity for the amino, imines and sulfydryl groups hence need to be removed from wastewater before discharge into the environment [2]. Also, it is believed that embarking on the separation of silver from wastewater is useful to encourage scientific research and create employment. Briefly, during film processing, exposed silver-halide crystals in emulsion are turned into black metallic silver, but unexposed crystals are not changed. Hence the light sensitive crystal is turned into black metallic silver thereby darkening clear areas of the film until completely black [3]. A number of possible technologies are available to separate silver from processing solutions. Among these there are chemical precipitation, metallic replacement, and electrolytic. Others are ion exchange, reverse osmosis and evaporation or distillation. The latter three are mostly called concentration technologies and are rarely viable options except for very large facilities [4]. Silver metal usually is alloyed with small amounts of other metals to make it harder and more durable. Sterling silver for tableware and other solid-silver objects is 92.5 percent silver and 75 percent copper [5]. Silver is used to coat smooth glass surface for mirrors by vaporization of the metal or by precipitation from a solution and widely used in electrical and electronic components. Colloidal silver, dilute solutions of silver nitrate $\left(\mathrm{AgNO}_{3}\right)$, and some insoluble compounds such as potassium can be used in medicine as antiseptics and bactericides. For example, argyrols, a silver-protein compound is a local antiseptic for the eyes, ears, nose and throat.

Silver halide salts such as silver bromide, silver chloride and silver iodide, which darkens on exposure to light are used in emulsions for photographic plates, films, and paper. The salts are soluble in sodium thiosulphate, which is the compound used in the photographic fixing process. Photographic films constitute heavy metal pollutants and contain silver that form stable compounds not readily removed by oxidation or by any other natural processes [2]. This work is thus focused on separation of metal silver from industrial wastewater using electrochemical method to reduce the concentration of the heavy metal in effluent discharges and the pollution effect to the environment through an economical procedure.

\section{Methodology}

The liquid samples used in this research experiment were collected from two different photo-laboratories Agfa and Konica laboratories in Minna, Niger State, Nigeria. They are henceforth refer as sample 1 and sample 2 except otherwise stated. Each sample was a collection of the waste discharges for three days. The carbon rods (anode) were fitted on the internal side of the $1000 \mathrm{~mL}$ beaker with a circular stainless steel cup (cathode) attached to the cover of the beaker, immersed into the liquid waste inside the beaker. The required agitation was provided through a mixer immersed in the liquid waste. The cathode was connected to the negative variable DC source while the anode was connected to the positive DC source. The initial weight of the cathode was measured and recorded. $800 \mathrm{~mL}$ of sample 1 was measured, filtered and transferred into the $1000 \mathrm{~mL}$ beaker. The mixer and the variable DC current source were switched on with initial 0.6 A current value based on preliminary experiment. The plating was checked after the elapsed time $0.25 \mathrm{~h}$ when a black coating was noticed. The current was reduced till when lighter plating was observed on the cathode. The cathode was removed, air dried, weighed, and the amount of silver recovered was measured. The procedure was repeated for the time interval $0.25-1.0 \mathrm{~h}$ with currents of $0.5 \mathrm{~A}, 0.4 \mathrm{~A}$, and $0.3 \mathrm{~A}$ for both samples in each case, the time, current and weight for each run was measured and recorded.

\section{Results and Discussion}

The research shows feasibility and facile method employed to separate silver from photographic wastewater, which has remained an environmental pollutant even till now [6]. An electrolytic method was used in the process silver recovery from two different samples of wastewater. The results showed that recovery of $2.3 \mathrm{~g}, 0.8$ g, $0.5 \mathrm{~g}$ and $0.3 \mathrm{~g}$ were obtained from sample 1 and a recovery of $2.8 \mathrm{~g}, 1.6 \mathrm{~g}, 0.9 \mathrm{~g}$, and $0.3 \mathrm{~g}$ from sample 2 at the time interval range of $0.25-1.0 \mathrm{~h}$ at $0.6 \mathrm{~A}$, respectively. The obtained results revealed that with increase in the current applied, the higher is the silver recovery from the solution. It can also be deduced that the higher the concentration of silver in the wastewater, the higher the recovery. It can be noticed that sample 1 had initial silver concentration of $3.2 \mathrm{~g} / \mathrm{L}$ and sample 2 had an initial silver concentration of $7.8 \mathrm{~g} / \mathrm{L}$ therefore more of the silver was recovered from sample 2 . The electrolytic method enables high amount of silver to be separated from the wastewater therefore making the method economical compared to other methods. For example, it is cheaper than extraction from natural sources which contain more impurities than the electrolytic method [6]. The inves- 
tigation revealed that the highest amount of silver obtained was $5.6 \mathrm{~g}$ from sample 2 which was possible through confines of the experiment setup. In both samples, the amount of silver in the waste reduced to $0.1 \mathrm{~g}$ before it was discarded to the environment after the experiment whereby it is less hazardous [7] [8].

With a variable AC/DC converter, the silver recovery was performed at four different currents that is; $0.6 \mathrm{~A}$, $0.5 \mathrm{~A}, 0.4 \mathrm{~A}$, and $0.3 \mathrm{~A}$, and the results obtained are plotted as a function of mass of recovered silver versus time. Figure 1 shows the plot for the recovered metal at $0.6 \mathrm{~A}$ where the highest recovery was obtained for sample 2 .

It was revealed in the plot that the amount of silver recovered at $0.6 \mathrm{~A}$ within the time interval gave a steep rise relationship in the mass of silver metal for both samples which was sustained until after $0.25 \mathrm{~h}$ where a steep decline was observed. Sample 2 obtained higher recovery than sample 1 with the maximum plating for both samples occurred at $0.6 \mathrm{~A}$ and $0.25 \mathrm{~h}$. Similar plots revealed the same pattern as shown in Figure 2 for the metal recovery at $0.5 \mathrm{~A}$.

Figure 2 also gave the relationship between the amount of silver recovered at $0.5 \mathrm{~A}$ and time, for an interval of $0.25 \mathrm{~h}$. The graph shows a steep rise for the first $0.25 \mathrm{~h}$ which is very similar as compared with that obtained for $0.6 \mathrm{~A}$, but in this case, the weight at the maximum is less than that obtained at $0.6 \mathrm{~A}$. This means that more of the solid matter was deposited using a higher current. There was also a steep drop after the first $0.25 \mathrm{~h}$ for about $0.25-0.33 \mathrm{~h}$, and then the drop became more gradual. This suggests that economically, the entire plating

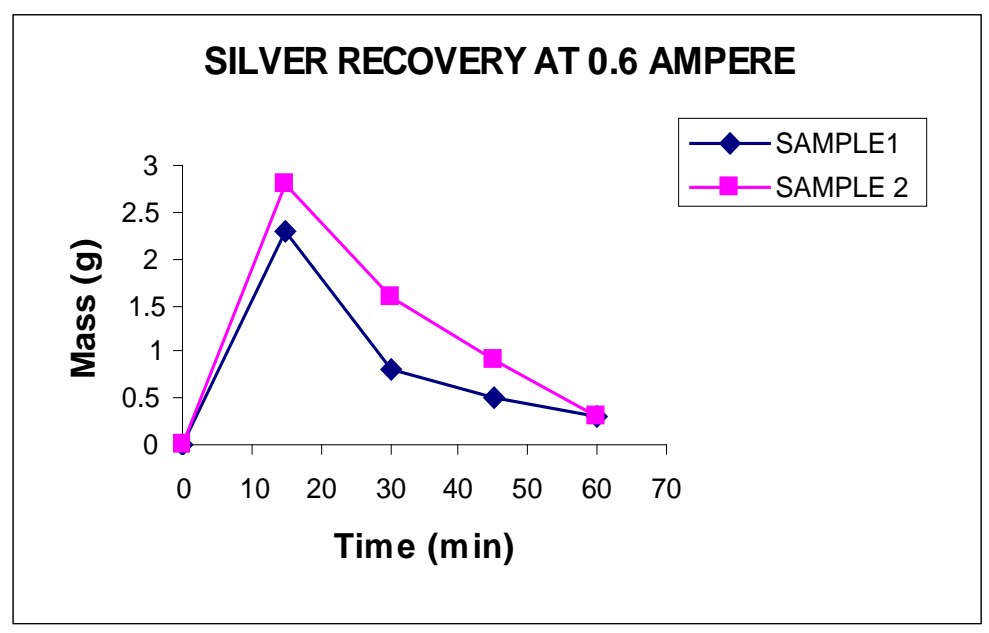

Figure 1. Mass silver recovered at 0.6 A for sample 1 and sample 2 in the time range of 0 - $60 \mathrm{~min}$.

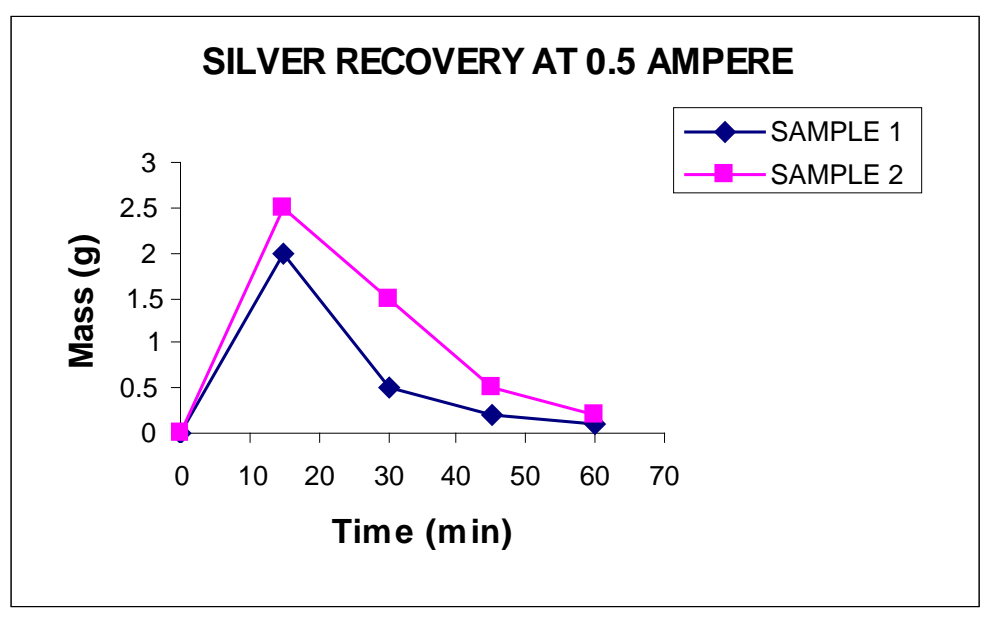

Figure 2. Mass of silver recovered at 0.5 A for sample 1 and sample 2 in the time range of $0-60 \mathrm{~min}$. 
time for samples at 0.5 A should not exceed $1.0 \mathrm{~h}$. In the same vein, as obtained in Figure 3, the amount of silvermetal in the discarded wastewater was $0.1 \mathrm{~g}$ in sample 2 compared to $0.2 \mathrm{~g}$ of sample 1 . Figure 3 gave the relationship between the amount of silver recovered and the time of plating. In this case, the graph showed a steep rise in the first $0.25 \mathrm{~h}$ and gradual drop in the amount deposited after the first $0.25 \mathrm{~h}$. The current of $0.4 \mathrm{~A}$ seems to favour the recovery of silver from sample 2 much more than sample 1 this can be observed by the large difference in weights obtained as shown on the graph.

Figure 4 gave the relationship of weight of silver recovered with time. Although there was a steep rise in the recovered mass in the first $0.25 \mathrm{~h}$, both samples had a very low recovery. Which suggests that $0.3 \mathrm{~A}$ is not economical for recovery in the process under investigation. The graph of cumulative recovery for silver for $0.6 \mathrm{~A}$ is as shown Figure 5. The pattern was similar for 0.5 A, 0.4 A, and 0.3 A (figures not shown).

\section{Conclusion}

The method employed in the investigation to separate silver metal from photo laboratory wastewater using electrolytic method was successful. The obtained silver metal attached as a chain onto the surface of a circular stainless steel material (cathode) during the setup. It was revealed that amount of recovered metal increase with the current applied as the time progressed with highest at $0.6 \mathrm{~A}$ in the time range of $0.25-1.0 \mathrm{~h}$. The method of

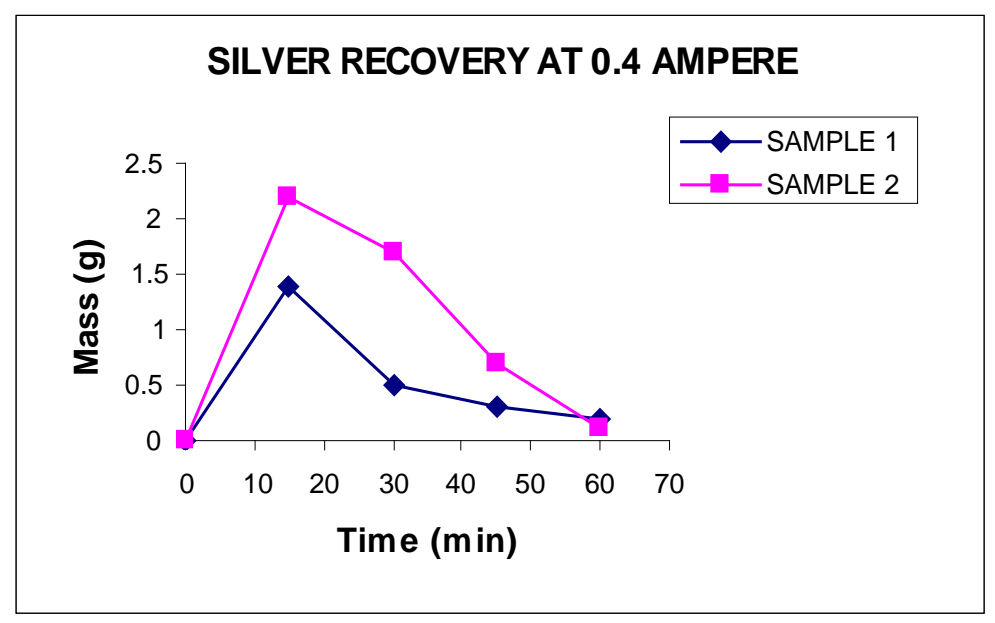

Figure 3. Mass of silver recovered at $0.4 \mathrm{~A}$ for sample 1 and sample 2 in the time range of $0-60 \mathrm{~min}$.

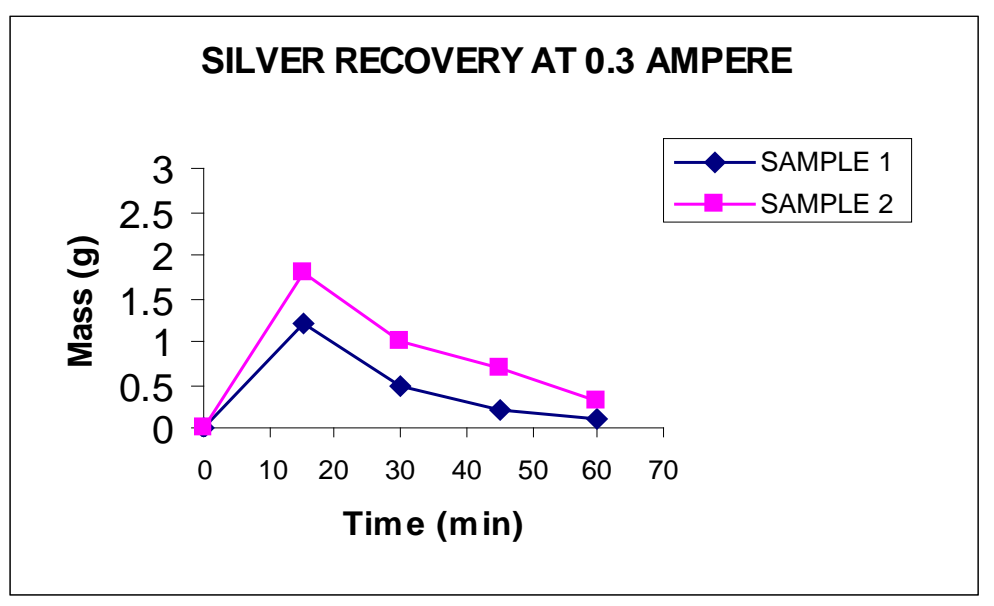

Figure 4. Mass of silver recovered at 0.3 A for sample 1 and sample 2 in the time range of $0-60 \mathrm{~min}$. 


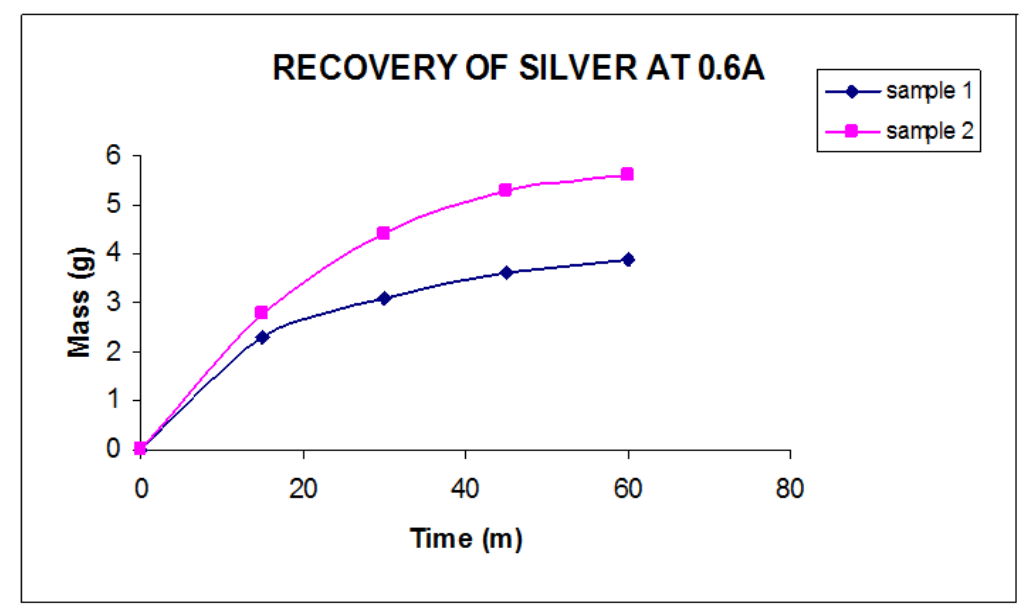

Figure 5. Cumulative mass of silver recovered at 0.6 A for sample 1 and sample 2 .

fered abatement of the environmental pollution caused by the industrial wastewater from photo laboratories.

\section{References}

[1] Luoma, S.N. (2008) Silver Nanotechnologies and the Environment: Old Problems or New Challenges? Project on emerging Nanotechnologies, Woodrow Wilson International Center for Scholars, 1-72.

[2] Company, K. (1979) Recovery of Silver from Photographic Materials. Kodak Environmental Information J-110, Eastman Kodak Company, New York, 2-5.

[3] Heller, W.G. and LeSchack, A.R. (1981) Military Geodesy and Geospace Science Unit Three—Scientific Report No. 7. The Analytic Sciences Corporation, Reading, 1-171.

[4] Tom Sandy, P.E. and Cindy Disante, P.E. (2010) Review of Available Technologies for the Removal of Selenium from Water. Prepared for North American Metals Council, 1-233.

[5] Ncjewelers.org/jewelry_info/silver1.html'access date $1^{\text {st }}$ February 2014.

[6] Robinson and Stokes (1955) Electrolyte Solutions. 2nd Edition, Academic Press, New York, 30-37.

[7] Othman, K. (1987) Encyclopedia of Chemical Technology. 3rd Edition, Volume 18, 275-310.

[8] Waite, J. (1997) Photographic Chemistry. University of Houston College of Technology, Houston, 1-11. 
Scientific Research Publishing (SCIRP) is one of the largest Open Access journal publishers. It is currently publishing more than 200 open access, online, peer-reviewed journals covering a wide range of academic disciplines. SCIRP serves the worldwide academic communities and contributes to the progress and application of science with its publication.

Other selected journals from SCIRP are listed as below. Submit your manuscript to us via either submit@scirp.org or Online Submission Portal.
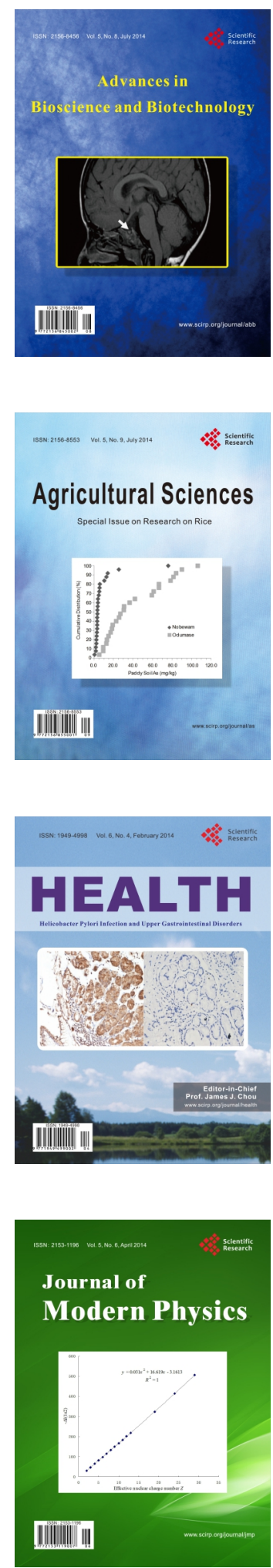
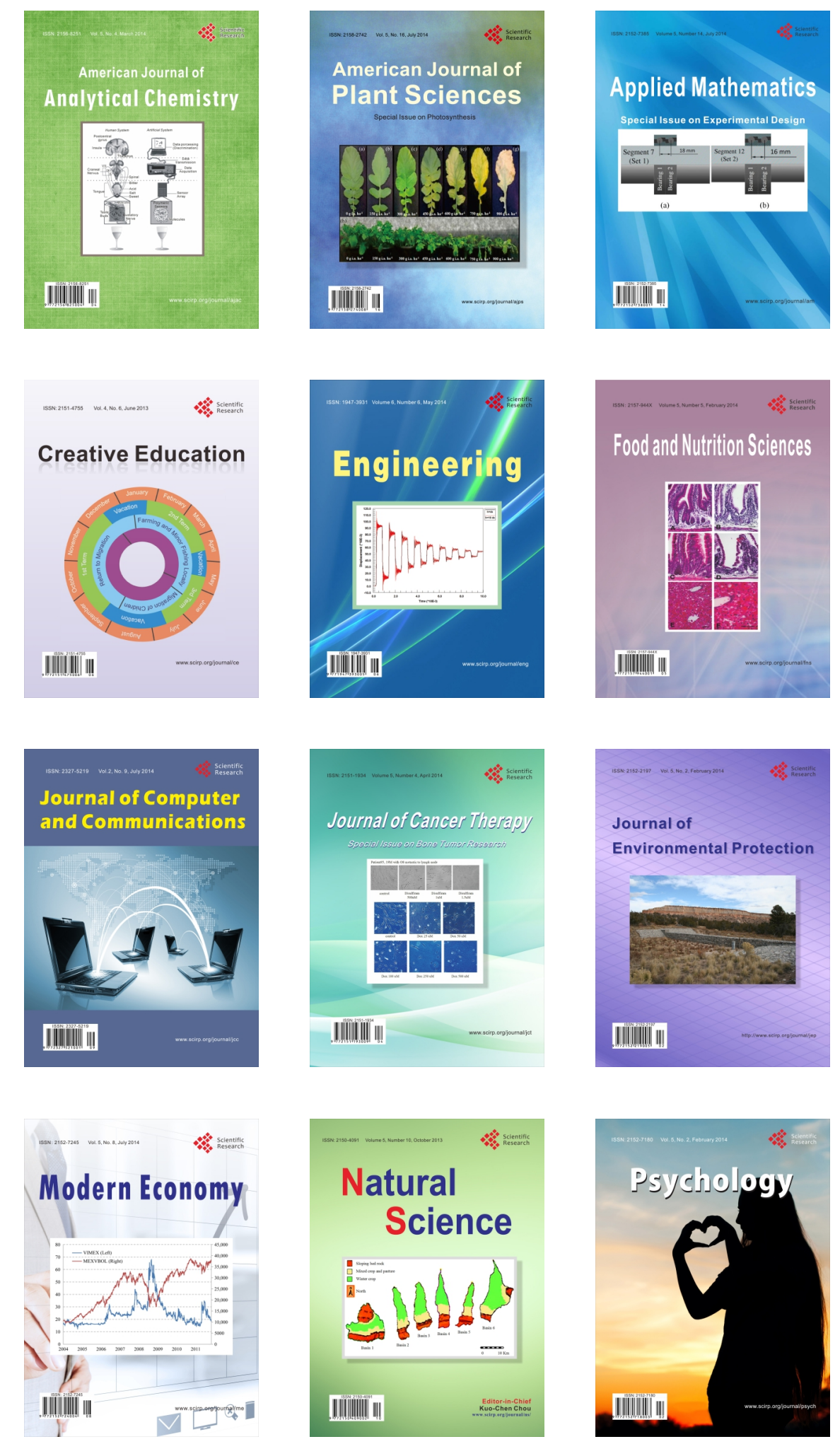